\title{
Morfologia comparada de três espécies de Stenocerus (Coleoptera, Anthribidae, Anthribinae)
}

\author{
Ailton Conceição de Oliveira Junior ${ }^{1,2}$ \& José Ricardo M. Mermudes ${ }^{1}$
}

${ }^{1}$ Laboratório de Entomologia, Departamento de Zoologia, Universidade Federal do Rio de Janeiro, Caixa Postal 68044, 21941-971 Rio de Janeiro-RJ, Brasil.
aibio@hotmail.com; jrmermudes@gmail.com
${ }^{2}$ Bolsista de Iniciação Científica PIBIC-CNPq.

\begin{abstract}
Comparative morphology of three species of Stenocerus (Coleoptera, Anthribidae, Anthribinae). Detailed studies of exoskeleton, mouthparts, wing venation, endosternites, retal plates and male and female terminalia, has been used to improve the systematics and evolutionary studies of the Neotropical anthribids. In this approach $S$. fulvitarsis (type-species of the genus), $S$. longulus and $S$. frontalis were carefully compared including descriptions and illustrations of characters never studied. Among the species examined, $S$. frontalis display a distinct mimetic pattern with flies of the family Sarcophagidae. The hypothesis that this species does not belong in the genus Stenocerus when compared with the type-species and S. longulus is discussed based mainly on position of the eyes, lack of lateral carinae, lamina of metendosternite longer than arms and median rods of ovipositor narrowed in the proximal region.
\end{abstract}

KEYWORDS. Curculionoidea; Neotropical; Stenocerini; systematics.

RESUMO. Morfologia comparada de três espécies de Stenocerus (Coleoptera, Anthribidae, Anthribinae). Estudos detalhados da morfologia do exoesqueleto, peças bucais, venação alar, endosternitos, placas esclerotizadas do intestino posterior e genitálias do macho e da fêmea, foram utilizados para aprimorar a sistemática e evolução de antríbideos neotropicais. Nesta abordagem, S. fulvitarsis (espécie-tipo do gênero), S. longulus e $S$. frontalis foram minuciosamente comparadas, incluindo as redescrições e ilustrações de caracteres nunca antes estudados. Dentre as espécies analisadas, $S$. frontalis apresenta um distinto padrão mimético com dípteros da família Sarcophagidae. A hipótese desta espécie não pertencer ao gênero se comparada com a espécie-tipo e $S$. longulus é discutida com base principalmente na posição dos olhos, ausência de carenas laterais, metendosternito com lâminas laterais mais curtas que os braços e hastes medianas do ovipositor estreitas na porção proximal.

PALAVRAS-CHAVE. Curculionoidea; Neotropical; Stenocerini; sistemática.

O gênero Stenocerus Schoenherr, 1826, juntamente com outros sete gêneros, foi alocado por Lacordaire (1866) no "Groupe VIII. Phloeophilides", por apresentar: (1) rostro deprimido, com a base mais estreita que a cabeça, mais ou menos longo e largo, quase sempre carenado, fracamente chanfrado no ápice, escrobos foveiformes e descobertos; (2) antenas curtas em ambos os sexos, com clava bem distinta, de três, muito raramente quatro artículos; (3) olhos finamente facetados, inteiros, laterais, oblongos e ovais; (4) carenas protorácicas variáveis, não alcançam o meio do protórax.

De acordo com Jordan (1906), Lacordaire (op cit.) propôs grupos de espécies no gênero com base somente nas diferenças da forma do protórax e élitros e, como tentado anteriormente por Jekel (1855), não pode ser sustentado. O próprio Jordan (op. cit) chamou a atenção para o padrão do processo mesosternal.

Atualmente, Stenocerus possui oito espécies, sendo o único gênero neotropical na tribo Stenocerini que inclui outros dezesseis gêneros (Alonso-Zarazaga \& Lyal 1999, 2002). Uma revisão do gênero foi feita por Valentine (1980), mas nenhum detalhe da morfologia interna foi estudado. O gênero Stenocerus é reconhecido por apresentar cerdas longas entre os artículos antenais III ao XI, protórax com carena sub-basal e processo mesosternal geralmente mais largo que a metade da cavidade cotilóide mediana. A forma do processo mesosternal juntamente com o padrão das carenas no rostro são caracteres importantes para o diagnóstico das espécies, como visto anteriormente por Jordan (1906) e Valentine (1980). Futuramente estes caracteres em conjunto com àqueles resultados dos estudos atuais no gênero Stenocerus fornecerão a base para uma investigação filogenética inédita.

Enquanto a maioria das espécies do gênero apresenta revestimento de pubescência preta combinada com castanha ou amarela, Stenocerus frontalis Gyllenhal, 1833 tem um padrão de colorido único, com o vértice vermelho, limitada por uma faixa amarela e angulosa. Esta espécie é parte de um complexo envolvendo várias famílias de coleópteros (Anthribidae, Buprestidae, Cleridae, Curculionidae e Mordellidae) que são miméticos de dípteros, com colorido similar ao das famílias Tachinidae e Sarcophagidae (Hespenheide 1973; Valentine 1980).

Este trabalho objetivou estudar a morfologia comparada de Stenocerus fulvitarsis (Germar, 1824) (espécie-tipo do gênero), S. longulus Jekel, 1855 e S. frontalis Gylenhal, 1833, visando obter novos caracteres morfológicos que contribuam para a definição de Stenocerus, bem como esclarecer se $S$. frontalis apresenta evidências para permanecer no gênero. 


\section{MATERIAL E MÉTODOS}

Foram estudados 16 exemplares de S. fulvitarsis, 54 de $S$. longulus e 22 de $S$. frontalis pertencentes às seguintes instituições (nome dos respectivos curadores entre parênteses): DZUP, Departamento de Zoologia, Universidade Federal do Paraná, Coleção Pe. J. S. Moure, Curitiba, Brasil (L. Marinoni); INBC, Instituto Nacional de Biodiversidad, Santo Domingo de Heredia, Costa Rica (A. Solis); MNRJ, Museu Nacional, Universidade Federal do Rio de Janeiro, Rio de Janeiro, Brasil (M. A. Monné); MZSP, Museu de Zoologia, Universidade de São Paulo, São Paulo, Brasil (S. A. Vanin).

As mensurações foram obtidas com auxílio da câmera Moticam 1000 acoplada ao estereomicroscópio e o programa Motic Image Plus 2.0 e seguem Mermudes (2002): CT = comprimento total, distância entre a margem anterior do protórax e o ápice dos élitros; $\mathrm{CR}=$ comprimento do rostro, distância entre a margem basal do labro e a margem dos olhos; LAR = largura apical do rostro; LBR = largura basal do rostro; $\mathrm{DEO}=$ distância entre a margem posterior do escrobo e a margem anterior do olho; $\mathrm{MLO}=$ maior largura lateral do olho; $\mathrm{CP}=$ comprimento do protórax na linha longitudinal mediana; LP = largura do protórax na altura da carena antebasal; $\mathrm{CE}=$ comprimento do élitro, da margem anterior ao ápice; LE = largura dos élitros, na linha umeral.

Os métodos para dissecação, ilustrações e a terminologia utilizada seguem Mermudes (2002, 2003, 2005).

Para o estudo da morfologia foram dissecados um macho proveniente de Corupá (Santa Catarina, Brasil) e uma fêmea de Eunópolis (Bahia, Brasil) de S. fulvitarsis; um macho de Linhares (Espírito Santo, Brasil) e uma fêmea da Costa Rica (Estancia Q. Bonita) de S. longulus; e um macho e uma fêmea de $S$. frontalis do Corcovado, Rio de Janeiro (Rio de Janeiro, Brasil).

\section{Stenocerus Schoenherr, 1826}

Stenocerus Schoenherr, 1826: 39; Alonso-Zarazaga \& Lyal, 1999: 34 (cat.); Rheinheimer, 2004: 38 (cat.)

Espécie-tipo: Anthribus fulvitarsis Germar, 1824.

Distribuição do gênero: Estados Unidos (Texas) ao Paraguai.

\section{Stenocerus fulvitarsis (Germar, 1824)}

(Figs. 7, 10, 13, 16, 19, 22, 27, 28, 31, 32, 37, 40, 43, 46, $49,52,53,56,60,63,66,69,72,75,76,79,82,85,86,91$, 92, 97, 100, 103, 106, 107)

Anthribus fulvitarsis Germar, 1824: 174 (Localidade-tipo: Brasil).

Stenocerus fulvitarsis (Germar, 1824); Schoenherr, 1826: 39; Zherikhin \& Gratshev, 1995: 636, fig. 19 (morf.); Valentine, 1980: 290 (rev.); Rheinheimer, 2004: 38 (cat.).

Stenocerus anatinus Perty, 1832: 68 (Localidade-tipo: Brasil, "Prov. Minarum” provavelmente Ouro Preto)

Stenocerus fulvipes Lacordaire, 1866: 524 (lapsus para fulvitarsis).

Macho. Tegumento castanho-escuro a preto. Pilosidade do revestimento dorsal: rostro branco-acinzentada intercaladas com castanho-clara, curta, decumbente e moderadamente densa; vértice com três faixas tênues amarelas, a mediana mais longa. Antenas subglabras ou com pilosidade esbranquiçada e esparsa. Antenômeros III-XI com cerdas longas e esparsas (Fig. 16); IX-XI com densa pilosidade castanha, curta e densa. Pronoto, élitros e pigídio revestidos com densa pilosidade castanha intercalada com branco-amarelada. Pronoto castanho-claro e branco-acinzentado, na metade anterior com três manchas subarredondadas castanho-escuras a pretas, lados da depressão central com uma mancha escura mais desenvolvida e irregular e duas basais junto das carenas e da margem posterior. Base dos élitros (Figs. 1, 2) castanhoclara e escura, esbranquiçada e amarelada; na base. Todas as interestrias ímpares (1-7) com padrão enxadrezado conspícuo: manchas irregulares castanho-escuras alternadas com áreas claras pouco mais longas; nas interestrias escutelar, 2, 4 e 6 , pilosidade esbranquiçada mais nítida. Pilosidade ventral, dos fêmures e das tíbias castanho-clara e branco-amarelada, curta, decumbente. Tarsômeros I e II com longa pilosidade amarelada e densa, no $\mathrm{V}$ mais curta e esparsa.

Cabeça (Figs. 7, 10, 13) ligeiramente mais longa que larga. Vértice com micronódulos densos. Olhos proeminentes, laterais e finamente facetados. Rostro cerca de uma vez e meio mais longo que a largura da base; dorso pontuadocorrugado com carena mediana elevada que estende-se do ápice e ultrapassa o vértice; carenas dorso-laterais pouco elevadas e curtas, desde o meio até a base do rostro; superfície ventral com pontuação fina e esparsa, elevada no meio e deprimida aos lados, com fóvea a cada lado da depressão; lados do rostro sinuosos, densamente pontuado-corrugados. Sulco subocular raso. Escrobo (Fig. 10) oval, moderadamente raso, com a margem superior projetada e carenada. Labro convexo, mais largo que longo. Mandíbulas (Figs. 19, 22) com a largura da base menor que o comprimento total; margem externa ligeiramente curva, mais acentuada no ápice, este aguçado e projetado; margem interna com dois dentes pouco desenvolvidos próximo ao meio; mola basal desenvolvida, sub-retangular e fortemente côncava. Maxila (Figs. 27, 28): gálea cilíndrica, alcança a base do artículo apical, com o ápice truncado dotado de um tufo de cerdas diferenciadas; lacínia apicalmente truncada, com dentes lacinais ventrais no terço apical, dorsal- e ventralmente com cerdas longas e densas; palpo com os artículos I e II subiguais em comprimento. Lábio com palpígeros fusionados (Figs. 31, 32) e artículo apical apendiculado. palpos labiais com artículos curtos e cilíndricos, o basal ligeiramente mais curto que o apical, segundo artículo mais longo, articulo apical com ápice subarredondado. Lígula alcançando o terço apical do segundo artículo, com os lados arredondados, lobos laterais desenvolvidos com chanfro arredondado e amplo, pilosidade alongada na porção apical e na base do chanfro.

Antenas (Fig. 16) curtas, ultrapassam o meio do protórax; escapo um terço mais curto que o pedicelo, este ligeiramente mais longo e engrossado para o ápice, subigual à metade do antenômero III, que o mais longo; IV ligeiramente mais curto que o III, V-VIII decrescentes no comprimento; IX-XI comprimidos, com faixa mediana subglabra e brilhante tanto dorsal- como ventralmente; IX levemente mais longo que o $\mathrm{X}$, IX-XI subiguais em comprimento. 


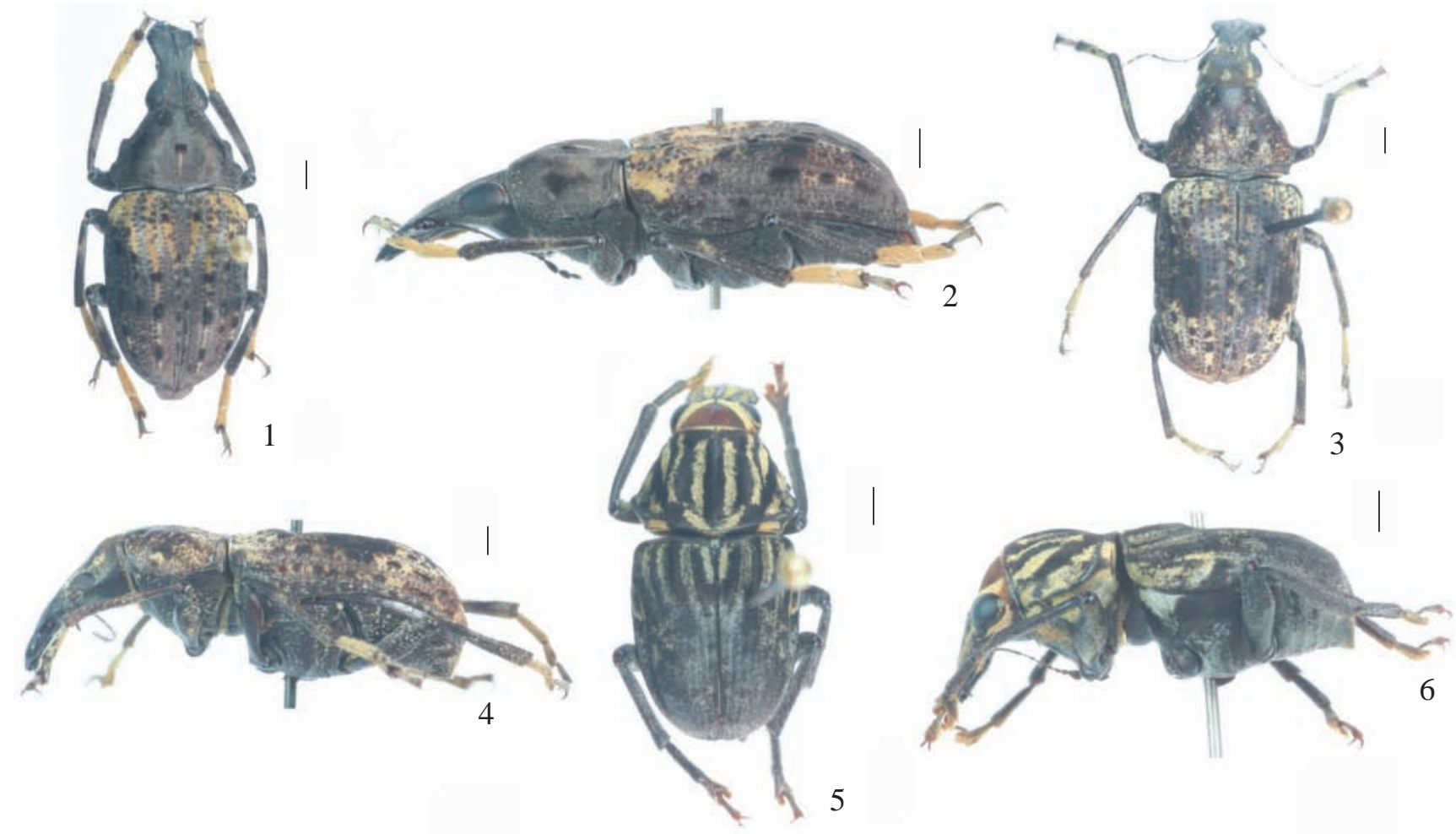

Figs. 1-6. Stenocerus fulvitarsis (Germar, 1824), macho: 1, dorsal, 2, lateral. Stenocerus longulus Jekel, 1855, macho: 3, dorsal, 4, lateral. Stenocerus frontalis Gyllenhal, 1833, macho: 5, dorsal, 6, lateral. Escala $=1 \mathrm{~mm}$.

Pronoto (Fig. 37) mais largo que longo, com depressão moderadamente rasa e uma discreta gibosidade central. Carena sub-basal (Figs. 37, 40) ligeiramente curva no meio e bissinuosa para os lados. Carena lateral longa, saliente, ligeiramente recurva na porção anterior, alcança o terço apical do protórax. Declive posterior (Figs. 37, 40, 43) estreito e vertical após a carena secundária; margem posterior elevada com unidades brácteas evidentes e esparsas. Carena sub-basal com unidades brácteas diminutas e aproximadas. Carena lateral sem unidades brácteas. Prosterno microesculturado e corrugado com aspecto noduloso. Proendosternito (Fig. 43) desenvolvido, com projeções individualizadas, afastadas entre si, dirigidas para o dorso do protórax, ligeiramente divergente, acuminado no ápice. Mesosterno cerca de 1,3x mais longo que o metasterno; processo mesosternal (Figs. 46, 49) desenvolvido com tubérculo mediano muito discretamente projetado anteriormente; em vista anterior, mais largo que a largura da cavidade cotilóide. Mesoscuto com projeção láteroanteriores atenuadas, superfície do disco com diminutos nódulos adensados (Fig. 53). Escutelo retangular com base ligeiramente côncava e ápice arredondado. Mesendosternito (Fig. 52) alongado, curvo e dirigido para o mesepimero, com aba lateral interna truncada e ampla, expandido no ápice. Metasterno com raros pontos rasos; à margem anterior entre as mesocoxas conspicuamente elevada para acomodar o processo mesosternal, com aspecto de pequenas abas verticais; sulco da margem anterior moderadamente profundo; metendosternito (Fig. 56) com lâminas retas e pouco mais curtas que os braços, perpendiculares ao pedúnculo; projeções medianas pouco desenvolvidas e com tendões anteriores afastados entre si; braços pouco alongados, divergentes entre si, com projeção interna, pedúnculo alongado e estreito. Élitros (Figs. 1, 2) curtos com lados paralelos, arredondados no terço apical; disco elitral com gibosidades basais e estrias pontuadas mais evidentes. Asas (Fig. 60): comprimento da região apical (distância entre o ápice da célula radial $(\mathrm{Rc})$ e $o$ ápice da asa), ligeiramente mais longo que o comprimento da região basal (base da asa ao ápice da célula radial). Subcosta (Sc) alongada, subigual à metade do comprimento da radial (R), transversas cu-a e 1a-2a vestigiais, terceira anal (3A) fracamente esclerotizada, cerca de $1,5 \mathrm{x}$ mais curta que $\mathrm{o}$ comprimento da $1 \mathrm{~A}_{2}$.

Abdome (Figs. 63, 66). Ventritos I-IV fortemente deprimidos no disco, I curto, II e III subiguais e V amplamente emarginado no ápice, duas vezes mais longo que o IV. Ventritos II e III, a cada lado disco, com uma leve depressão e com discreto tubérculo. Pigídio (Fig. 72) com o comprimento da porção basal elevada, subigual a metade apical, margem apical truncada. Intestino posterior com placas retais esclerotizadas (Fig. 75): a ventral um pouco mais curta que as laterais, dorsal pouco mais longa que as laterais, alça retal truncada e oblíqua. Terminália: Oitavo tergito (Fig. 76) pouco mais longo que largo, esclerotizado apenas lateralmente e no ápice, lados subparalelos, extremidade com o chanfro amplo (largura do chanfro cerca de $3 \mathrm{x}$ maior que a largura de cada um dos lobos), e cerdas curtas e densas; oitavo esternito (Fig. 79) membranoso, com lobos láteroapicais esclerotizados e apódema pouco desenvolvido; nono esternito (=espícula gástrica) (Fig. 82) com apódema não estreitado no ápice, pelo menos quatro vezes mais longo que 

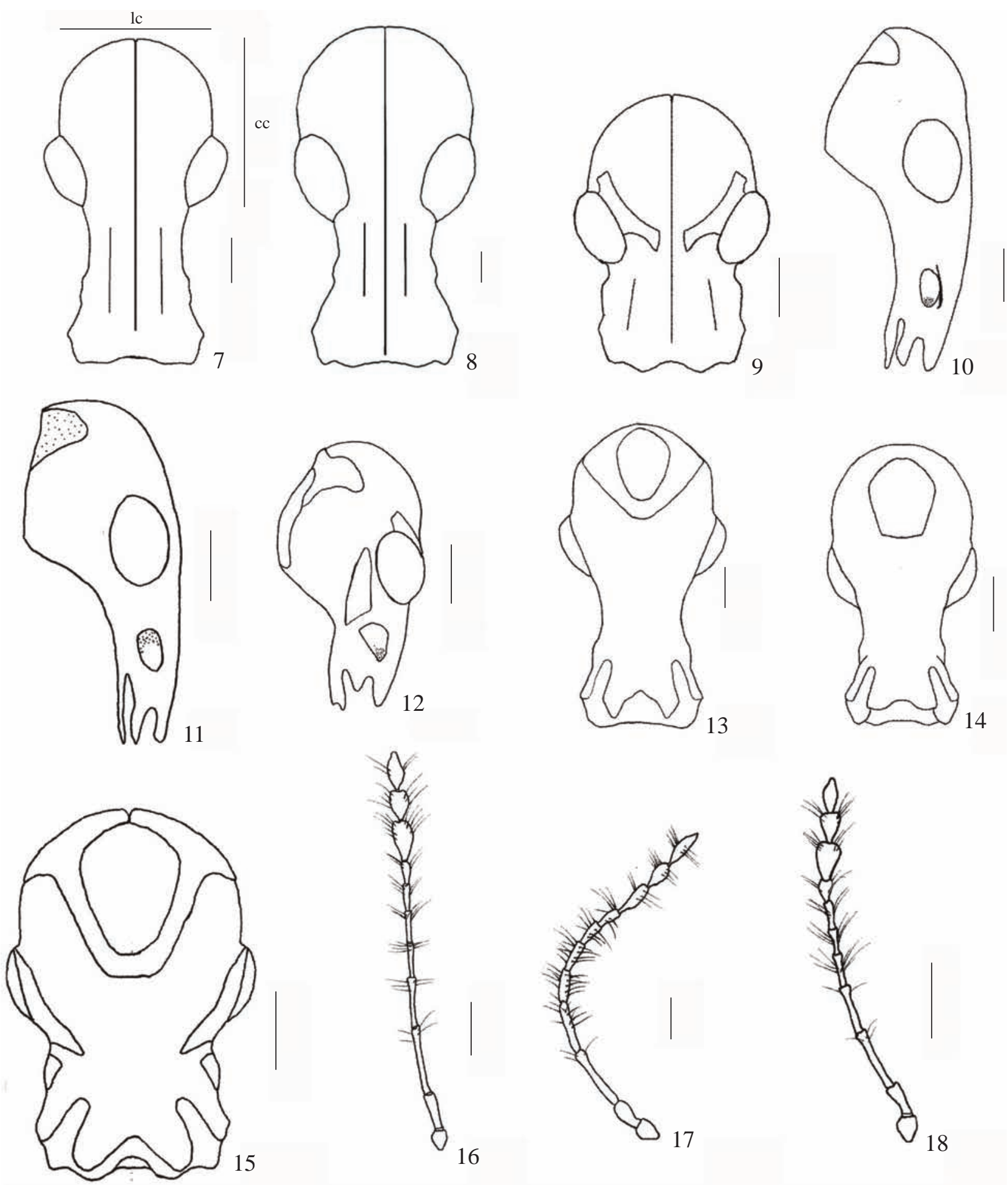

Figs. 7-18. 7-15, cabeça, macho, vistas dorsal, lateral e ventral, respectivamente: 7, 10, 13; Stenocerus fulvitarsis; 8, 11, 14, S. longulus; 9, 12, 15, S. frontalis. 16-18, antena, macho: 16, S. fulvitarsis; 17, S. longulus; 18, S. frontalis; lc = largura da cabeça; $c c=$ comprimento da cabeça. Escala $=1 \mathrm{~mm}$.

os braços. Tégmen (Figs. 85, 86) com apódema ligeiramente menor que o comprimento do anel esclerotizado, este com as margens pigmentadas, bordo pré-apical chanfrado, parâmeros fusionados e conspicuamente alargados na base. Edeago (Figs. 91, 92) alongado e sub-retilíneo, corpo subigual à metade do comprimento dos apódemas; ponte entre os apódemas levemente esclerotizada; tectum membranoso, acuminado no ápice, cerca de uma vez e meio mais longo que largo, com os bordos fortemente esclerotizados e pigmentados; pedon contínuo com os apódemas, lados divergentes no terço basal e divergentes no terço apical, apódemas algo engrossados para a base. Saco interno com o comprimento ligeiramente menor que o comprimento dos apódemas, sem espículas, não lobado no forâmen e com duas hastes esclerotizadas. 
Fêmea. Antena ultrapassa a margem anterior do protórax pelo comprimento da clava. Rostro: comprimento do rostro cerca de uma vez e meio mais longo que a largura da base; sulco antenal oval com a margem inferior direcionada para a porção ventral do rostro. Ventrito V (Fig. 69) deprimido a cada lado do disco. Terminália: nono tergito (Fig. 97) cerca de cinco vezes e meio mais longo que a largura da base, subparalelo na região proximal. Oitavo tergito (Fig. 100) membranoso, pouco mais longo que largo, lados mais nitidamente pigmentados e ápice truncado-arredondado, dotado de cerdas. Oitavo esternito (Fig. 103) membranoso, comprimento desde o apódema cerca de duas vezes mais longo que a largura da região distal, margens laterais e região central nitidamente pigmentados e apódema fortemente esclerotizado. Ovipositor (Figs. 106, 107) cerca de duas vezes mais curto que as hastes laterais, lobo dorsal ausente, lobos ventrais, laterais e mediano acentuadamente acuminados; ápice esclerotizado, com três dentes subiguais e rombóides, estilos cilíndricos e curtos; hastes medianas delgadas, expandidas na região proximal, com comprimento entre a região das hastes transversas até o ápice menor que o comprimento das hastes laterais; bolsa copuladora desenvolvida, pelo menos $1,8 \mathrm{x}$ mais longa que as hastes laterais, com a superfície lisa em toda a sua extensão; espermateca e glândula da espermateca não observadas.

Dimensões em mm, macho/fêmea, respectivamente. CT = 7,9-14,3/9,0-13,9; CR = 1,6-3,1/2,0-3,1; LAR = 1,5-2,5/1,82,8; LBR = 1,2-1,7 /1,2-1,9; DEO = 0,6-1,2/0,6-1,2; MLO = 0,8-1,6/0,9-1,3; LP = 3,8-7,4/4,3-6,9; CP = 2,6-4,5/2,9-4,5; $\mathrm{CE}=5,3-8,1 / 6,1-9,4 ; \mathrm{LE}=4,2-9,8 / 4,8-7,6$.

Distribuição. Guianas, no Brasil (Amazonas, Mato Grosso, Goiás, Bahia, Minas Gerais, Rio de Janeiro, São Paulo, Santa Catarina) e Paraguai (Valentine,1980). Com base no material estudado, acrescentamos Brasil (Espírito Santo, Paraná).

Material examinado. BRASIL. Bahia: Eunópolis, macho, 13.I.1973, C. Elias col. (MNRJ). Espírito Santo: Santa Tereza, fêmea, 15-22.I.1968, C.T. Elias col. (MNRJ); Córrego Itá, fêmea, XI.1953, W. Zikan col. (MNRJ). Rio de Janeiro: Rio de Janeiro (Corcovado), fêmea, XII.1962, Alvarenga \& Seabra col. (Coleção M. Seabra) (MNRJ)(Floresta da Tijuca), macho, C. A. C. Seabra col. (MNRJ); (Lab. de Entomologia Agrícola, Museu Nacional), fêmea (sem data e coletor). Paraná: Araponga, fêmea, II.1952, A. Muller col. (MNRJ); Curitiba (Barigui), fêmea, 8.I.1945, Rolflé col. (Coleção F. Justus)(MNRJ); Guaraúna, fêmea, IV.1943 (Coleção F. Justus)(MNRJ); Ortigueira, 2 machos, XII.1988, Monné \& Roppa col. (MNRJ); Ponta Grossa (N. Rússia), macho, III.1958 (Coleção F. Justus)(MNRJ). Santa Catarina: Corupá, fêmea, XII.1953, A. Maller col. (Coleção Campos Seabra)(MNRJ); Indiana, macho, 10.III.1935, Schimith col. (MNRJ); Joinville, fêmea, 1920, Schimith col. (MNRJ).

Discussão. Stenocerus fulvitarsis possui revestimento semelhante ao de S. longulus, S. angulicollis Jekel, 1855 e S. varipes Fahraeus, 1839, mas difere destas por apresentar no pronoto manchas sub-arredondadas castanho-escuras e gibosidade central e élitros (Fig. 1), na base, com densa pilosidade amarelada e brilhante que revestem os úmeros e interestrias 1, 2, 3 e 5, além do processo mesosternal discretamente projetado anteriormente (Fig. 49). Em $S$. longulus, S. angulicollis e $S$. varipes o pronoto não tem o padrão de manchas castanho-escuras e a gibosidade central.
Nos élitros, a base nunca é nitidamente mais clara e o processo mesosternal é plano.

Quanto aos tarsômeros I e II com densa pilosidade amarelada, é semelhante a $S$. nigrotesselatus Blanchard, 1846, mas difere deste por apresentar nos élitros padrão de pilosidade enxadrezado em interestrias alternadas.

\section{Stenocerus longulus Jekel, 1855}

(Figs. 8, 11, 14, 17, 20, 23, 24, 29, 33, 34, 38, 41, 44, 47, 50, 54, 57, 61, 64, 67, 70,73, 77, 80, 83, 87, 88, 93, 94, 98, 101, 104, 108, 109)

Stenocerus longulus Jekel, 1855: 106 (Localidade-tipo: Brasil); Valentine, 1980: 291 (rev.); Rheinheimer, 2004: 38 (cat.).

Macho. Tegumento castanho-avermelhado a preto. Pilosidade do revestimento dorsal (Figs. 3, 4): rostro recoberto com castanho-clara, curta, pouco adensada na porção apical; fronte e vértice com manchas castanho-escuras intercaladas com castanho-claras; faixa com pilosidade amarelada densa, curta e decumbente a cada lado da fronte e uma mediana no vértice. Antenômeros IV-XI (Fig. 17) com cerdas longas e esparsas, clava (IX-XI) com pubescência castanho-clara e brilhante. Pronoto, élitros e pigídio com densa pilosidade irregularmente mesclada de amarelo, castanho-clara e- escura, mais densa nos lados da base do pronoto. Élitros (Figs. 3,4) com densa pilosidade amarelada nos terços basal e apical e, ao longo das interestrias $1,3,5$ e 7, padrão enxadrezado de manchas amareladas alternadas com manchas castanhoescuras; terço mediano com densa pilosidade castanhoescura. Pigídio amarelado moderadamente densa intercalada com manchas castanho-claras. Revestimento ventral e das pernas com inúmeras manchas diminutas branco-amareladas decumbente e moderadamente densa; porção mediana das tíbias com faixa anelar amarela. Tarsômeros I com densa pilosidade amarelada.

Cabeça (Figs. 8, 11, 14) levemente mais longa que larga, vértice convexo; vértice e fronte fortemente microcorrugado. Olhos proeminentes, laterais e finamente facetados. Rostro duas vezes mais longo que a largura da base, pontuado nos ângulos anteriores e pontuado-corrugado nas depressões entre as carenas; carena mediana acentuadamente elevada e longa do ápice até o vértice; carenas dorso-laterais curtas e pouco elevadas; margem apical algo angulosa no meio; superfície ventral com pontuação fina e espaçada; base do rostro elevada ao meio e deprimida aos lados com fóvea na depressão. Escrobo (Fig. 11) direcionado anteriormente. Labro mais largo que longo, convexo, no ápcie com cerdas castanhoescuras, longas e eretas. Mandíbulas (Figs. 20, 23, 24) com a largura da base menor que o comprimento total; ápice aguçado e projetado. Maxila (Fig. 29): gálea subcilíndrica, alcança a extremidade do segundo artículo do palpo, lateralmente com densa pilosidade alongada e ápice truncado dotado de longas cerdas; lacínia alongada atinge a base do segundo artículo do palpo, alargada na base estreitando-se em direção ao ápice, este truncado, margem interna fracamente côncava, região dorsal e ventral com longas cerdas densas; palpo maxilar com artículo basal curto e pouco esclerotizado, 

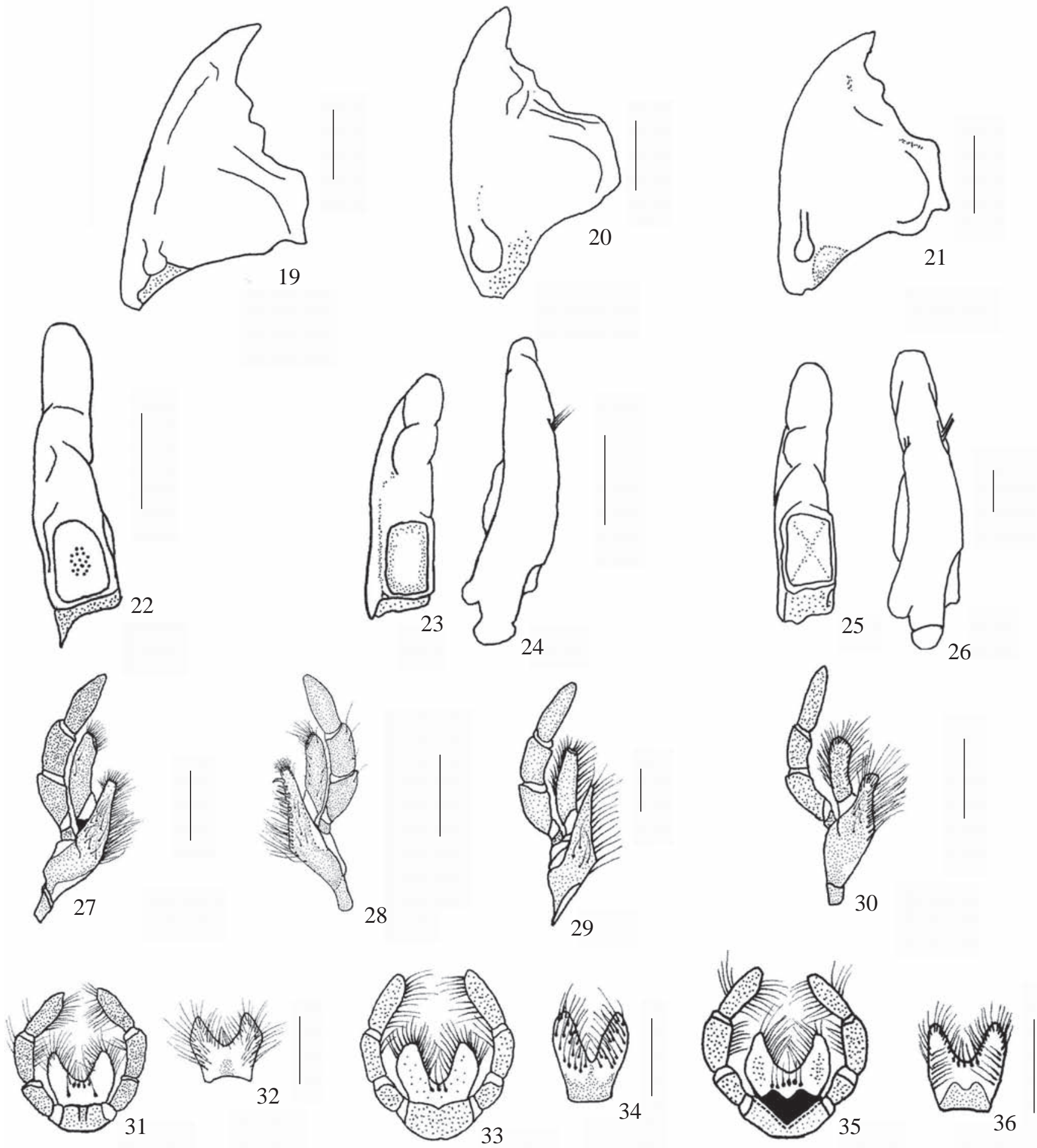

Figs. 19-36. 19-26, mandíbula: Stenocerus fulvitarsis, 19, ventral, 22, interna; S. longulus, 20, ventral, 23, interna, 24, externa; S. frontalis, 21, ventral, 25, interna, 26, externa. 27-30, maxila: S. fulvitarsis, 27, dorsal, 28, ventral; S. longulus, 29, dorsal; S. frontalis, 30 dorsal. 31-36, lábio ventral e lígula, face interna, respectivamente: 31, 32, S. fulvitarsis; 33, 34, S. longulus; 35, 36, S. frontalis. Escala $=0,5 \mathrm{~mm}$

terceiro artículo engrossado, algo mais longo que o segundo, este cilíndrico e quase um terço menor que o apical, que é alongado e pouco mais estreito no ápice. Lábio (Figs. 33, 34) com os palpígeros cilíndricos e fusionados; palpos labiais com artículos curtos e cilíndricos, o basal levemente menor que o apical, o segundo mais longo e artículo apical, o maior, com ápice subarredondado. Lígula alcança o terço apical do segundo artículo, com os lados arredondados, lobos laterais desenvolvidos e chanfro arredondado e profundo; pilosidade alongada na porção apical e na base do chanfro. Mento glabro, com a margem apical arredondada e superfície preenchida por densos pontos finos.

Antenas ultrapassam o terço mediano do pronoto; escapo (Fig. 17) um terço mais curto que o II e robusto; este engrossado 
para o ápice, antenômeros III-VIII comprimidos dorsoventralmente e expandidos no ápice; antenômero III o mais longo; IV levemente mais curto que o III; V-VIII decrescente no comprimento; IX-XI subiguais em comprimento, com elevação longitudinal e ligeiramente mais longos que $\mathrm{X}$.

Protórax (Figs. 38, 41, 44) cerca de uma vez e meio mais largo quelongo; pronotodeprimido, mais acentuadamenteperto da carena sub-basal; carena lateral longa, sinuosa, alcança o terço apical do protórax. Prosterno subglabro, com diminutos nódulos moderadamente adensados. Proendosternito com projeções individualizadas, subcilíndricas, pouco expandidas nos lados externos, afastadas entre si, dirigidas para o dorso do protórax e ligeiramente divergentes. Mesosterno micropontuado, subigual ao comprimento do metasterno; processo mesosternal (Figs. 47, 50) igual à largura da cavidade cotilóide, bituberculado e ápice profundamente deprimido no meio. Mesoscuto curvo na margem anterior, com projeções estreitas, superfície do disco com pequenos nódulos adensados (Fig. 54). Escutelo subretângular com ápice arredondado e densamente revestido de pilosidade curta. Metasterno com pontos finos. Metendosternito (Fig. 57) com lâminas pouco mais curtas que os braços, retas, perpendiculares ao pedúnculo; projeções medianas pouco desenvolvidas, com tendões anteriores afastados entre si, braços pouco alongados, divergentes, oblíquos às lâminas e com projeções internas membranosas; pedúnculo alongado e pouco estreito. Élitros (Figs. 3, 4) curtos, com lados paralelos, arredondados no terço apical; na base, com pontuação mais evidente e gibosidades atenuadas e estreitas. Asas (Fig. 61) desenvolvidas e pouca alongadas; comprimento da região apical (ápice da célula radial ao ápice da asa) ligeiramente mais longo que o comprimento da região basal (base da asa ao ápice da célula radial), este algo mais longo que a largura basal; subcosta (Sc) alongada, com a metade do comprimento da radial $(\mathrm{R})$; célula radial $(\mathrm{Rc})$ fechada, quadrangular e reduzida; setor radial (Rs) desenvolvido; transversa radialmédia (r-m) ligeiramente curva e pouco esclerotizada; média (M) desenvolvida, dirigida para a radial; primeira cubital $\left(\mathrm{Cu}_{1}\right)$ algo sinuosa; transversa (cu-a) vestigial, primeira anal $\left(1 \mathrm{~A}_{2}\right)$ presente, subigual à metade do comprimento da segunda anal (2A), terceira anal (3A) levemente esclerotizada, subigual ao comprimento da $1 \mathrm{~A}_{2}$; quarta anal $(4 \mathrm{~A})$ e jugal $(\mathrm{J})$ vestigiais.

Abdome (Figs. 64, 67). Ventritos I-IV deprimidos no disco, $\mathrm{V}$ giboso com depressão discreta próximo à margem. Pigídio (Fig. 73) com o comprimento da porção basal subigual à metade apical, margem apical truncadaarredondada. Terminália: oitavo tergito (Fig. 77) com os lados subparalelos, pouco mais longo que largo e cerdas curtas e densas, esclerotizado apenas lateralmente e no ápice, este com chanfro amplo (largura do chanfro cerca de duas vezes e meio maior que a largura de cada um dos lobos) e cerdas curtas e densas; oitavo esternito (Fig. 80) membranoso com definidos lobos látero-apicais definidos, esclerotizados e apódema bem desenvolvido; nono esternito (=espícula gástrica) (Fig. 83) com apódema pelo menos duas vezes e meio mais longo que os braços. Tégmen (Figs. 87, 88) com apódema subigual ao comprimento do anel esclerotizado, este basalmente com as margens pigmentadas; bordo préapical levemente chanfrado, parâmeros fusionados e conspicuamente alargados na base. Edeago (Fig. 93, 94) alongado, algo encurvado, com o corpo subigual à metade do comprimento dos apódemas; ponte entre os apódemas ligeiramente esclerotizada; tectum membranoso, alongado, quase duas vezes mais longo que largo, com os bordos fortemente esclerotizados e pigmentados; pedon contínuo com os apódemas, que são engrossados para a base; lados convergentes para o ápice acuminado. Saco interno um pouco mais longo que a metade dos apódemas, sem espículas, não lobado no forâmen e com duas hastes esclerotizadas.

Fêmea. Escrobo com margem anterior oblíqua. Olhos subarredondados. Pigídio plano. Ventritos I-IV convexos, V em cada lado do disco profundamente deprimido, centralmente com denso tufo de cerdas castanho-amareladas (Fig. 70). Terminália: nono tergito (Fig. 98) cerca de seis vezes mais longo que a largura da base, na porção proximal discretamente expandido lateralmente e medianamente pouco esclerotizada; hastes laterais alongadas, fortemente esclerotizadas. Oitavo tergito (Fig. 101) membranoso, levemente mais longo que largo, lados mais nitidamente pigmentados, ápice truncado e cerdas dispostas lateralmente. Oitavo esternito (Fig. 104) membranoso, comprimento desde o apódema quase duas vezes mais longo que a largura da região distal, lobos láteroapicais nitidamente pigmentados na região central, apódema esclerotizado. Ovipositor (Figs.108, 109) com corpo distinto das hastes laterais, cerca de duas vezes mais curto que estas; lobo dorsal ausente; lobos ventrais, laterais e mediano acentuadamente acuminados; ápice fortemente esclerotizado, com três dentes subiguais e rombóides, estilo cilíndrico e curto; hastes medianas delgadas, com comprimento entre a região das hastes transversas até o ápice menor que comprimento das hastes laterais, alcançando terço apical das hastes laterais; bolsa copuladora desenvolvida, pelo menos uma vez e meia mais longa que as hastes laterais, com pequenas rugas em toda a sua extensão; espermateca reniforme, mais estreita na porção apical; glândula da espermateca globosa.

Dimensões em mm, macho/fêmea, respectivamente. $\mathrm{CT}=$ 8,3-13,8/7,0-12,8; CR = 1,5-2,5/1,5-2,4; LAR = 1,4-2,4/1,42,2; LBR = 1,0-1,6/1,0-1,5; DEO = 0,4-0,8/0,3-0,9; MLO = 0,9-1,3/0,6-1,3; LP = 3,8-5,8/3,0-5,5; CP = 2,6-4,0/2,0-4,0; $\mathrm{CE}=5,7-9,8 / 5,0-8,8 ; \mathrm{LE}=4,2-6,4 / 3,4-6,2$.

Distribuição: Estados Unidos (Texas), México (Chiapas, Veracruz, San Luis Potosi), Costa Rica, Panamá, Trinidad, Guiana, Colômbia (Antioquia), Peru (Loreto, Junin), Brasil (Amazonas, Pará, Mato Grosso, Minas Gerais, Espírito Santo, Rio de Janeiro, São Paulo, Paraná e Santa Catarina) (Valentine 1980). Acrescentamos Brasil (Amapá e Rondônia).

Material Examinado. COSTA RICA. Puntarenas: Est. Q. Bonita, fêmea, IX.1993, 50m , R. Guzmão col., LN 194500-469850 \# 2349 (INBIO); Sirena, macho, 1-100m, 6-12.IV.1995, LN 2705000507900 \# 4573 (INBIO); (P.N. Corcovado), macho, 1-100m, II.1994, G. Fonseca col., LS 270500-508300 \# 2614 (INBIO). Guanacaste: Cacao, fêmea, VI.1990, Paratáxon, LN 323300 , 37570 (INBIO). Peru. San Martín: Tocache, fêmea, macho, 2.XI.1984, leg L. Huggert (MNRJ). BRASIL. Amapá: Serra do Navio, fêmea, XII.1998, Magno \& Costa col. (MNRJ). Amazonas: São Paulo de Olivença, fêmea, VIII.1945, H. C. Boy col. (MNRJ); Tabatinga, 2 machos, fêmea, IV.1978, Pereira col. (MNRJ); Benjamim Constant, macho, fêmea, III-IV. 1942, DZ 79/62 (MNRJ). Pará: Óbidos, macho, VIII.1922, H.L. Boy col. (MNRJ); Santarém, 2 fêmeas, I.1935 (Sem coletor), macho, IV.1978, Pereira col. (MNRJ); Serra 

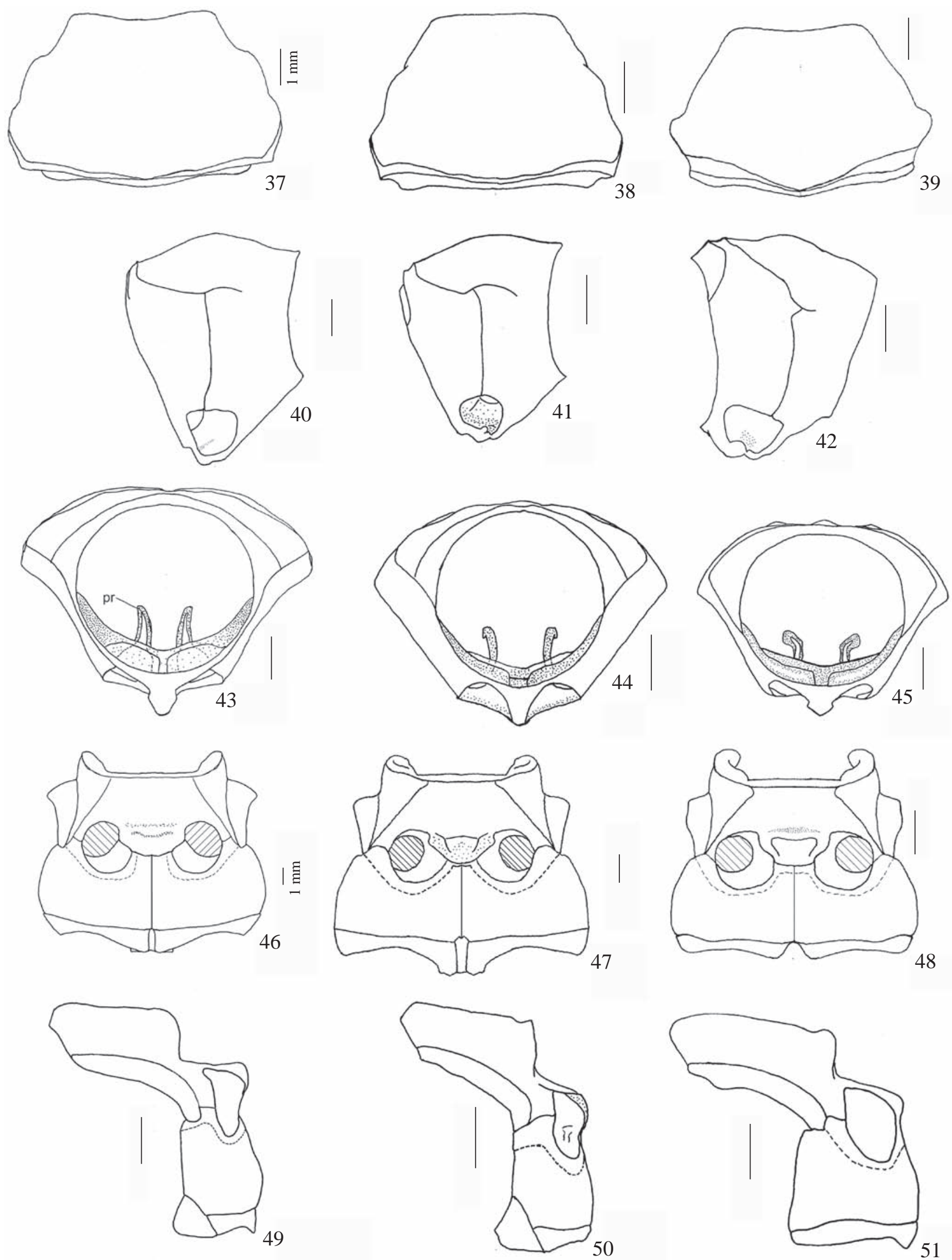

Figs. 37-51. 37-45, protórax, vistas dorsal, lateral e posterior, respectivamente: 37, 40, 43, Stenocerus fulvitarsis; 38, 41, 44, S. longulus; 39, 42, 45, S. frontalis. 46-51, meso- e metasterno vistas ventral e lateral, respectivamente: 46, 49, Stenocerus fulvitarsis; 47, 50, S. longulus; 48, 51, S. frontalis; pr = proendosternito. Escala $=1 \mathrm{~mm}$. 
dos Carajás, fêmea, II.1988 (sem coletor)(MNRJ), Ilha Outeiro, fêmea, 19.IX.1978 (MPEG). Rondônia: Ouro Preto do Oeste (Margem do Rio Santa Helena), fêmea, 30.III.1985, M.F. Torres col. (MPEG). Mato Grosso: Barra do Bugres, macho, XII.1984, Magno \& Alvarenga col. (MNRJ); Sinop (12³1'S 55³7’W), 163,350m, 3 machos, 2 fêmeas, X.1975, Alvarenga \& Roppa col.; macho, 2 fêmeas, X.1974, Alvarenga \& Roppa col. (MNRJ); Faz. Teles, 2 machos, X.1974, B. Silva col.; fêmea, X.1976, B. Silva col. (MNRJ). Espírito Santo: Linhares, 7 machos, 4 fêmeas, III-IV.1970, B. Silva col; macho, fêmea, II.1970, B. Silva col.; macho, X.1968 (sem coletor); macho, XII.1975, F.M. Oliveira col. (MNRJ); Córrego Itá, macho, fêmea, XI.1956, W. Zikan col.; macho, XI.1966, W. Zikan col., 2 machos, X.1954, W. Zikan col.; macho, I.1955, W. Zikan col. (MNRJ). Paraná: Araponga, fêmea, XI.1951, A. Maller col. (Coleção C. Seabra)(MNRJ).

Discussão: S. longulus apresenta revestimento semelhante a S. fulvitarsis e $S$. angulicollis, porém difere mais facilmente do primeiro pelos caracteres de $S$. fulvitarsis discutidos acima e pela ausência de dentes na lacínia. Distingue-se de $S$. angulicollis por apresentar carena mediana no rostro. (ausente em S. angulicollis).

\section{Stenocerus frontalis Gyllenhal, 1833}

(Figs. 9, 12, 15, 18, 21, 25, 26, 30, 35, 36, 39, 42, 45, 48, 51, $55,58,59,62,65,68,71,74,78,81,84,89,90,95,96,99$, $102,105,110,111)$

Stenocerus frontalis Gyllenhal, 1833 in Schoenherr, 1833: 169 (Localidadetipo: Brasil). Valentine, 1980: 291 (rev.); Rheinheimer, 2004: 38 (cat.).

Macho. Tegumento preto, vértice vermelho e antenas castanho-escuras. Pilosidade do revestimento dorsal: vértice e fronte, a cada lado e adjacente aos olhos, em faixa longa e arqueada de densa pilosidade amarelada, subdecumbente. Rostro com pilosidade amarelada, curta, brilhante e decumbente, mais densa nas depressões entre as carenas e à frente dos olhos. Antenômeros VIII-XI (Fig. 18) com pubescência castanho-clara à escura pouco densa. Pronoto com duas faixas centrais longitudinais amareladas e uma, a cada lado do disco; lateralmente, entre as carenas subbasal e secundária, manchas irregulares amareladas. Élitros (Figs. 5, 6), no terço basal, com faixas longitudinais cinzaamareladas e brilhantes nas interestrias escutelar, 2, 4 e 6 . Dois terços apicais com cinza brilhante e moderadamente densa, intercalados com castanho-clara; região mediana dos élitros com manchas castanho-escuras nas interestrias 3-5. Pigídio com branco-amarelada pouco densa. Revestimento ventral denso e decumbente, branco e brilhante. Porção lateral dos esternos e ventritos com castanho-escura. Face ventral do rostro e prosterno abaixo dos olhos e ao redor do sinus maxilar com densa pilosidade amarela. Lados do prosterno com manchas amareladas próximo à sutura pleural. Fêmures e tíbias com mescla de pilosidade branca e castanho-escura; tíbias e tarsômero I, com cerdas pretas longas e suberetas. Demais tarsômeros com densa pilosidade amarelo-clara e brilhante.

Cabeça (Figs. 9, 12, 15) tão larga quanto longa; vértice convexo com rugas finas e contíguas. Fronte fortemente corrugada. Olhos dorso-laterais, ovais e proeminentes. Rostro curto, mais largo que longo (largura da base cerca de $1,2 \mathrm{x}$ maior que o comprimento, da margem anterior do olho ao ápice do rostro); pontuado-corrugado; carena mediana e dorso-laterais ligeiramente elevadas, irregulares e lisas; carena mediana estende desde a margem anterior até a base do rostro; carenas dorso-laterais se estendem desde o nível dos escrobos até a margem anterior dos olhos; deprimido à frente dos olhos; margem apical ligeiramente arredondada no meio. Escrobo (Fig. 12) profundo, foveiforme, direcionado para a face ventral do rostro. Labro com cerdas eretas castanhoclaras. Mandíbulas (Figs. 21, 25, 26) com ápice pouco projetado; mola basal pouco côncava. Maxilas (Fig. 30): gálea alongada com ápice arredondado, alcança a base do artículo apical do palpo; lacínia atinge a base do segundo artículo do palpo, ápice arredondado, margem interna com tênue curva próxima ao ápice; palpos maxilares com o segundo artículo quase dois terços mais curto que apical. Lábio (Figs. 35, 36) com palpígeros individualizados, com chanfro mediano raso; lígula com lados subparalelos. Mento corrugado e na base com o rostro elevado e liso.

Antenas (Fig. 18): escapo piriforme, pedicelo tão curto quanto oescapo, antenômeros III-VIII fortementecomprimidos dorso-ventralmente e nodosos no ápice, antenômero III o mais longo, IV com dois terços do III, IV-VIII decrescente no comprimento, IX-XI com faixa longitudinal glabra dorsal- e ventralmente, IX algo mais longo que o X, subigual ao XI.

Protórax (Figs. 39, 42, 45) cerca de uma vez e meio mais largo que longo, lateralmente sinuoso. Pronoto microcorrugado, com duas depressões longitudinais profundas no disco. Carena sub-basal curva no meio, fortemente saliente e oblíqua para os lados. Superfície do prosterno, mesosterno e metasterno com pontos finos e densos. Proendosternito desenvolvido, com projeções individualizadas, afastadas entre si, dirigidas lateralmente e fortemente divergentes. Mesosterno ligeiramente mais longo que o metasterno; processo mesosternal (Figs. 48, 51) mais largo que a cavidade cotilóide, levemente deprimido no ápice e com tubérculos laterais pouco desenvolvidos. Mesoscuto (Fig. 55) algo curvo na margem anterior, com projeções látero-anteriores e superfície do disco com diminutos nódulos adensados; escutelo mais largo que longo, pentagonal, com a base ligeiramente côncava. Metendosternito (Figs. 58, 59) com lâminas nitidamente mais longas que os braços, perpendicular ao pedúnculo, projeções medianas pouco desenvolvidas e tendões anteriores subcontíguos entre si; braços curtos, divergentes, oblíquos às lâminas, com projeção interna, pedúnculo alongado e pouco estreito. Élitros deprimidos após o terço basal; terço basal com interestrias 1 e 3 salientes; interestrias escutelar e 4 deprimidas; epipleura deprimida após o úmero. Asas (Fig. 62) alongadas, subcosta (Sc) três vezes menor que o comprimento da radial (R), transversas cu-a e $1 \mathrm{a}-2 \mathrm{a}$ vestigiais, jugal $(\mathrm{J})$ com a metade do comprimento da quarta anal (4A).

Abdome (Figs. 65, 68). Ventritos I-IV decrescentes em comprimento, I-III uniformemente convexos, ventrito I com uma fraca gibosidade próxima à sutura com o II, ventrito IV algo deprimido a cada lado do disco, $\mathrm{V}$ pouco mais longo que o IV. Pigídio (Fig. 74) com a porção basal elevada cerca de um terço do comprimento do pigídio, margem apical arredondada. Terminália: oitavo tergito com os lados subparalelos (Fig. 78) pouco mais longo que largo, esclerotizado apenas nas 

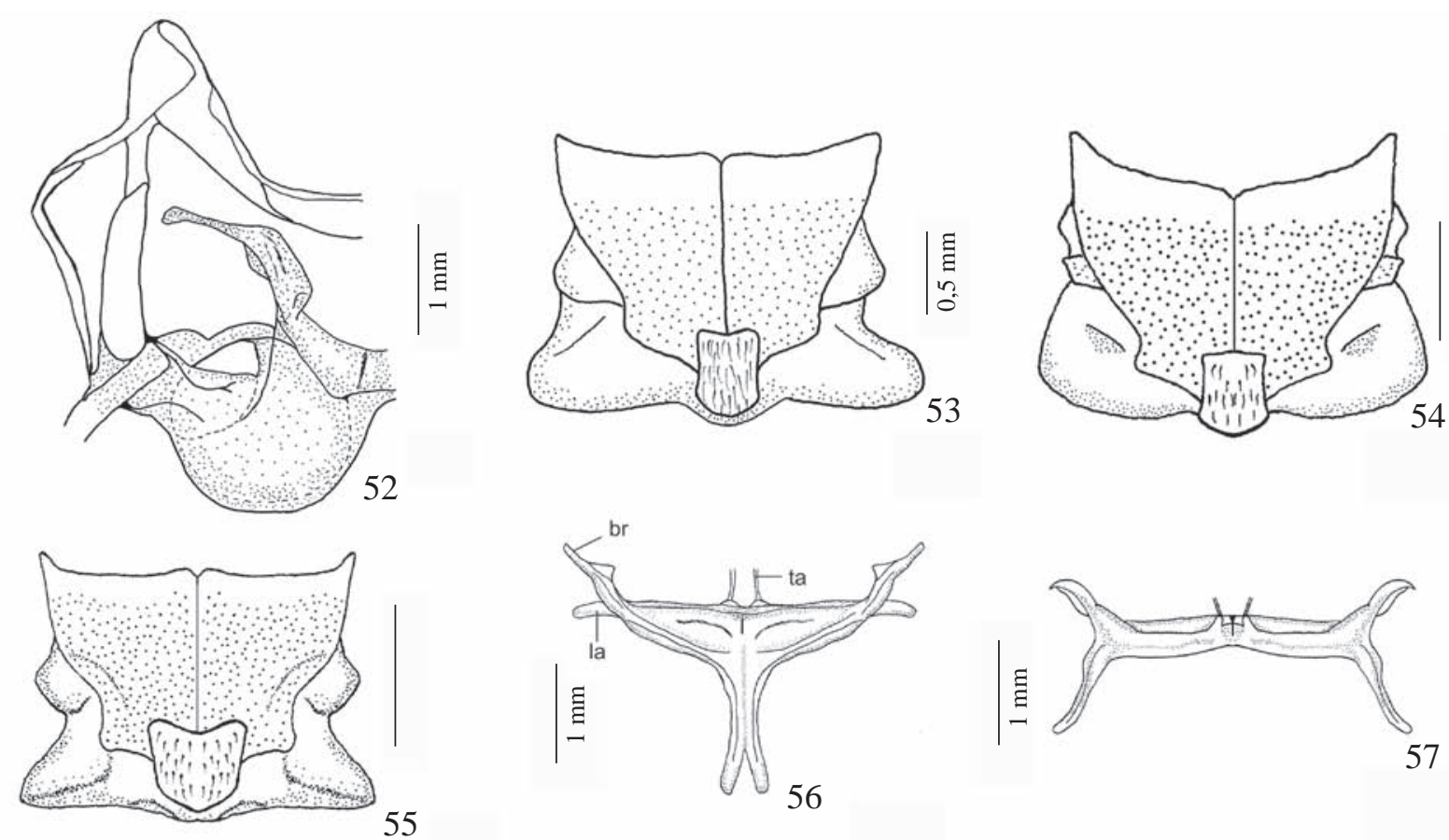

55
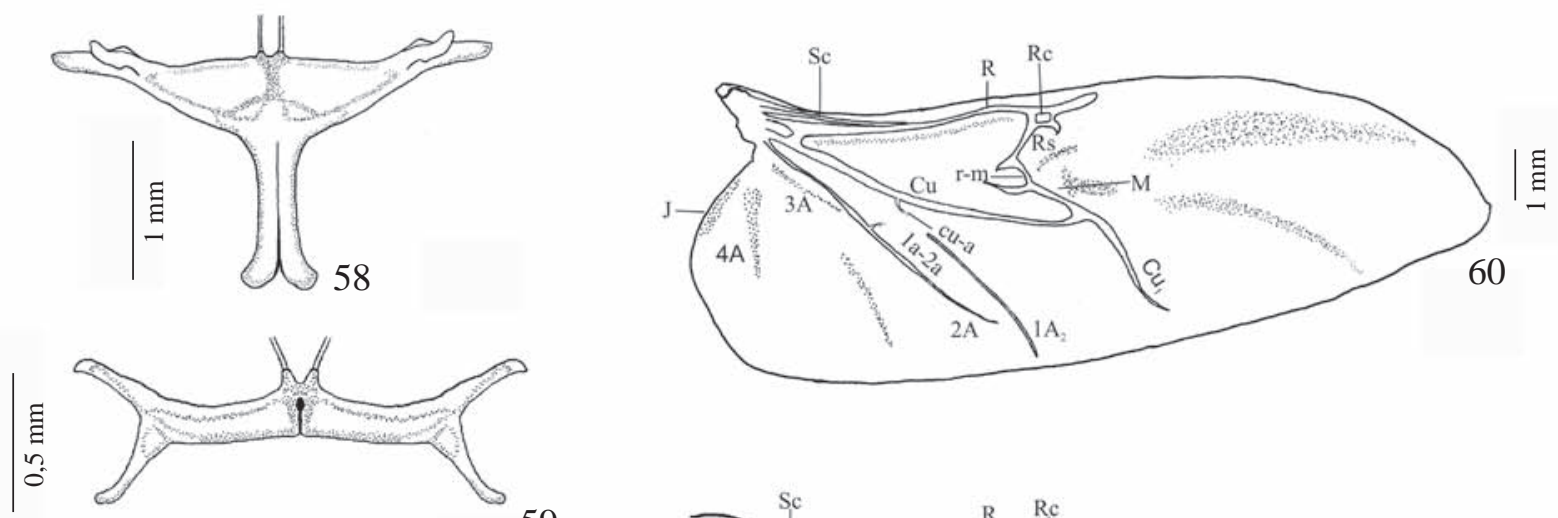

59
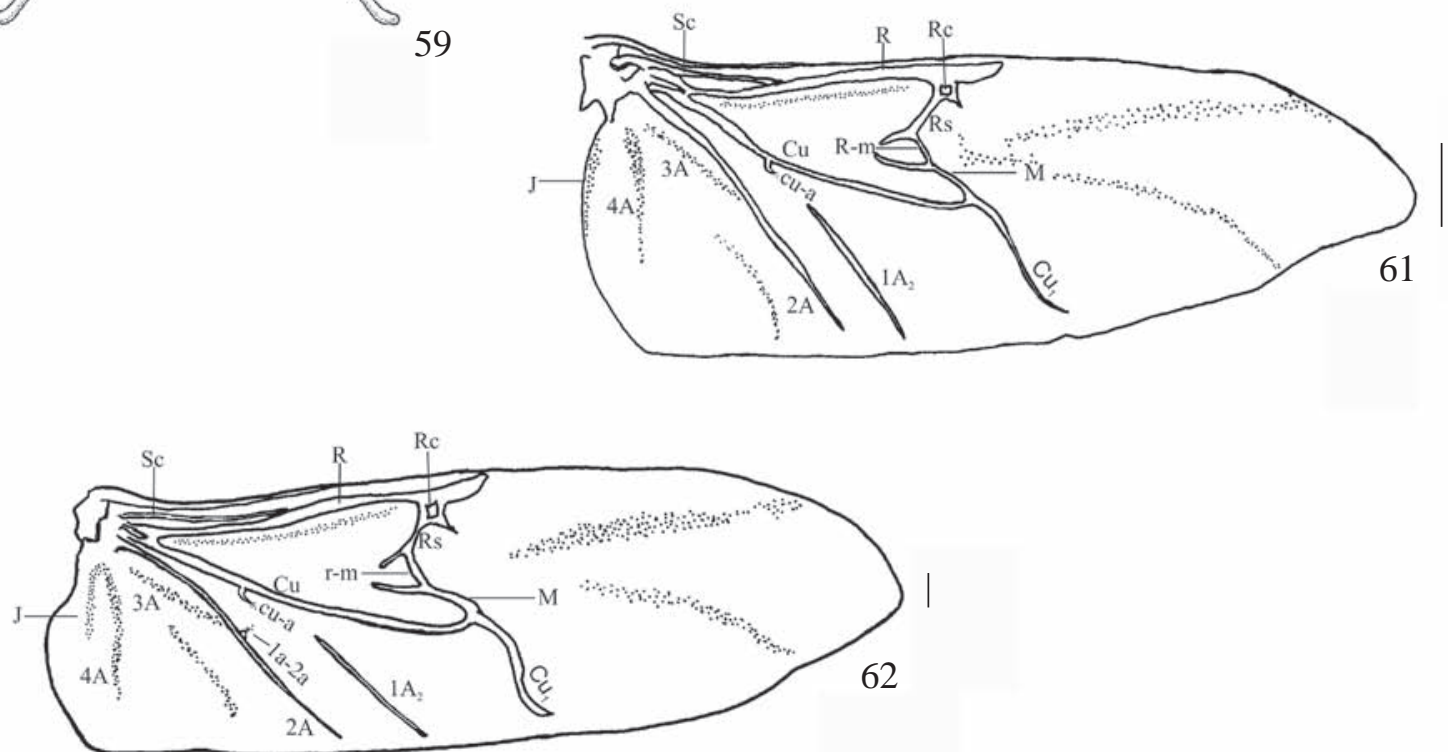

Figs. 52-62. Mesendosternito: 52, Stenocerus fulvitarsis. 53-55, mesoscuto e escutelo: 53, S. fulvitarsis; 54, S. longulus; 55, S. frontalis. 56-59, metendosternito: S. fulvitarsis, 56, dorso-posterior; S. longulus, 57, superior; S. frontalis, 58, dorso-posterior, 59, superior. 60-62, asa: 60, S. fulvitarsis; 61, S. longulus; 62, S. frontalis; br = braço; la = lâmina; ta = tendões anteriores; $\mathrm{Sc}=$ subcosta; $\mathrm{R}=$ radial; $\mathrm{Rc}=$ célula radial; $\mathrm{Rs}=$ setor radial; $\mathrm{r}-\mathrm{m}=$ transversa radial média; $\mathrm{Cu}=$ cubital, $\mathrm{Cu}_{1=}$ primeira cubital, $\mathrm{M}=$ média; $\mathrm{cu}-\mathrm{a}=$ transversa cubital anal; $1 \mathrm{~A}_{2}=$ segundo ramo da primeira anal; $2 \mathrm{~A}=$ segunda anal; $1 \mathrm{a}-2 \mathrm{a}=$ transversa $1^{\mathrm{a}} 2^{\mathrm{a}}$; $3 \mathrm{~A}=$ terceira anal; $4 \mathrm{~A}=$ quarta anal; $\mathrm{J}=$ jugal. Figs. 52,56-58,60-62 e 53-55,59 na escalas de $1 \mathrm{~mm}$ e $0,5 \mathrm{~mm}$, respectivamente. 

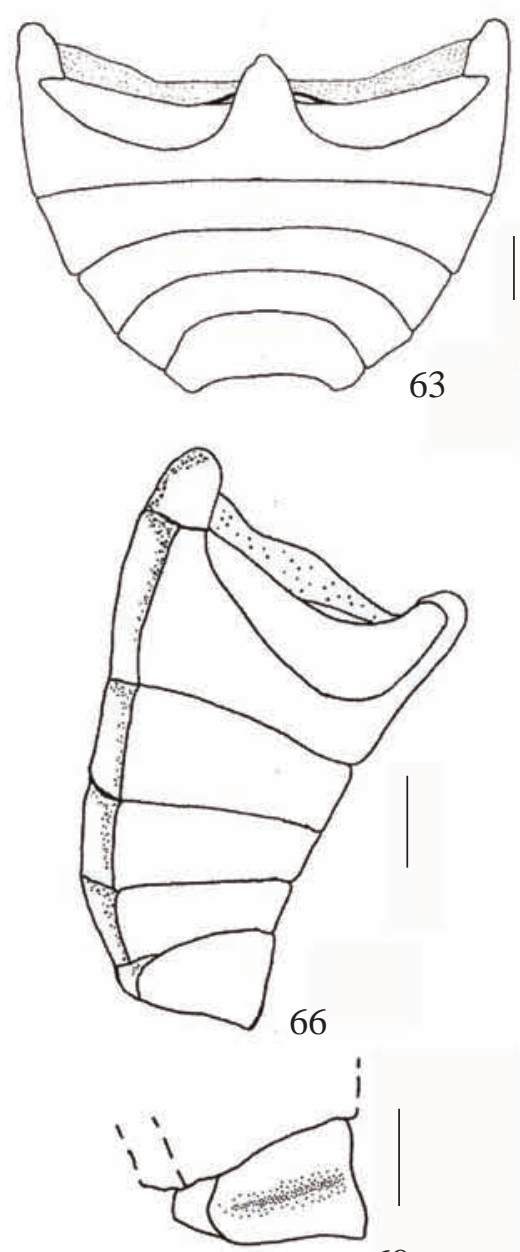

69

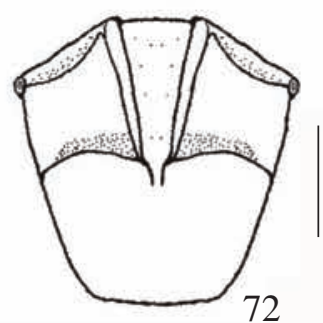

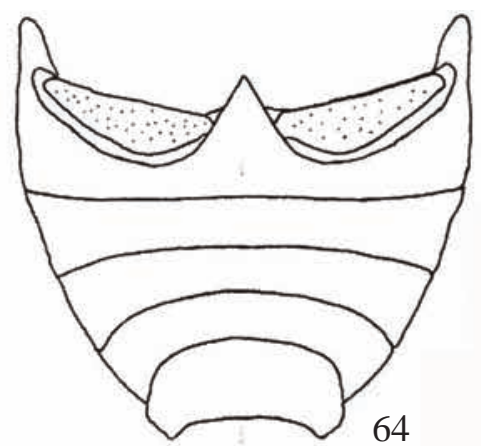
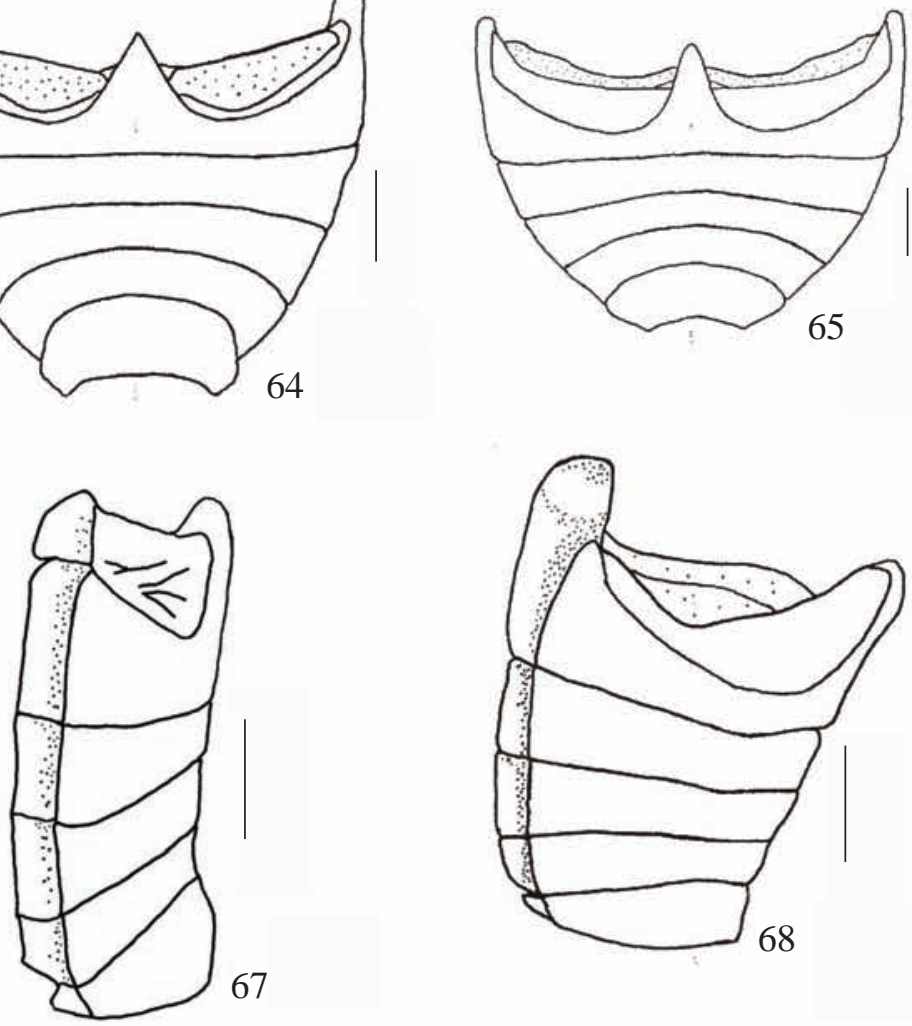

67
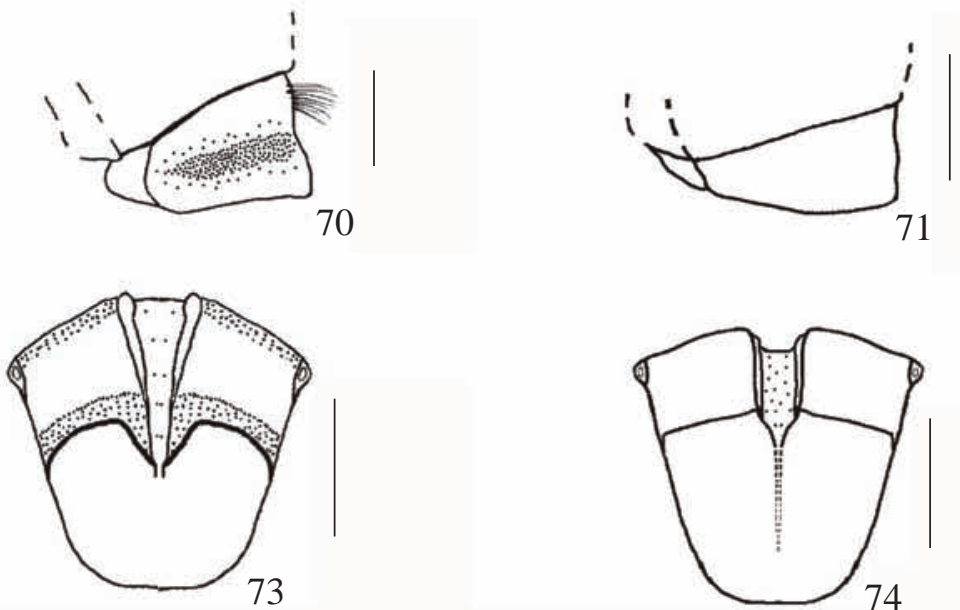

Figs. 63-74. 63-68, abdome, macho, vistas ventral e lateral, respectivamente: 63, 66, Stenocerus fulvitarsis; 64, 67, S. longulus; 65, 68, S. frontalis. 69-71, abdome, fêmea, vista lateral: 69, S. fulvitarsis; 70, S. longulus; 71, S. frontalis. 72-74, pigídio: 72, S. fulvitarsis; 73, S. longulus; 74, S. frontalis. Escalas = $1 \mathrm{~mm}$.

margens laterais e no ápice, este com chanfro curto (largura do chanfro subigual à largura dos lobos laterais) e cerdas longas e densas; oitavo esternito (Fig. 81) membranoso com lobos látero-apicais esclerotizados e definidos, apódema ausente; nono esternito (=espícula gástrica) (Fig. 84) com apódema pelo menos 1,5x mais longo que os braços. Tégmen (Figs. 89, 90) com apódema pouco mais curto que o anel esclerotizado, este com as margens laterais na base pigmentados; bordo préapical algo chanfrado, parâmeros fusionados. Edeago (Figs. 95, 96) alongado e levemente curvado; corpo subigual à metade do comprimento dos apódemas; ponte entre os apódemas ligeiramente esclerotizada; tectum membranoso, alongado, quase duas vezes mais longo que largo, com os bordos fortemente esclerotizados e pigmentados; pedon contínuo com os apódemas, lados acentuadamente convergentes no ápice, este acuminado; apódemas engrossados para a base. Saco interno aproximadamente um terço mais longo que os apódemas, sem espículas, com amplas áreas pigmentadas dorsal- e ventralmente.

Fêmea. Rostro com a largura basal cerca de 1,2x maior que o comprimento do rostro, da margem anterior do olho ao ápice do rostro. Ventrito $\mathrm{V}$ um terço mais longo que o IV (Fig. 71). Terminália: nono tergito (Fig. 99) cerca de quatro vezes mais longo que a largura da base, com lados discretamente 

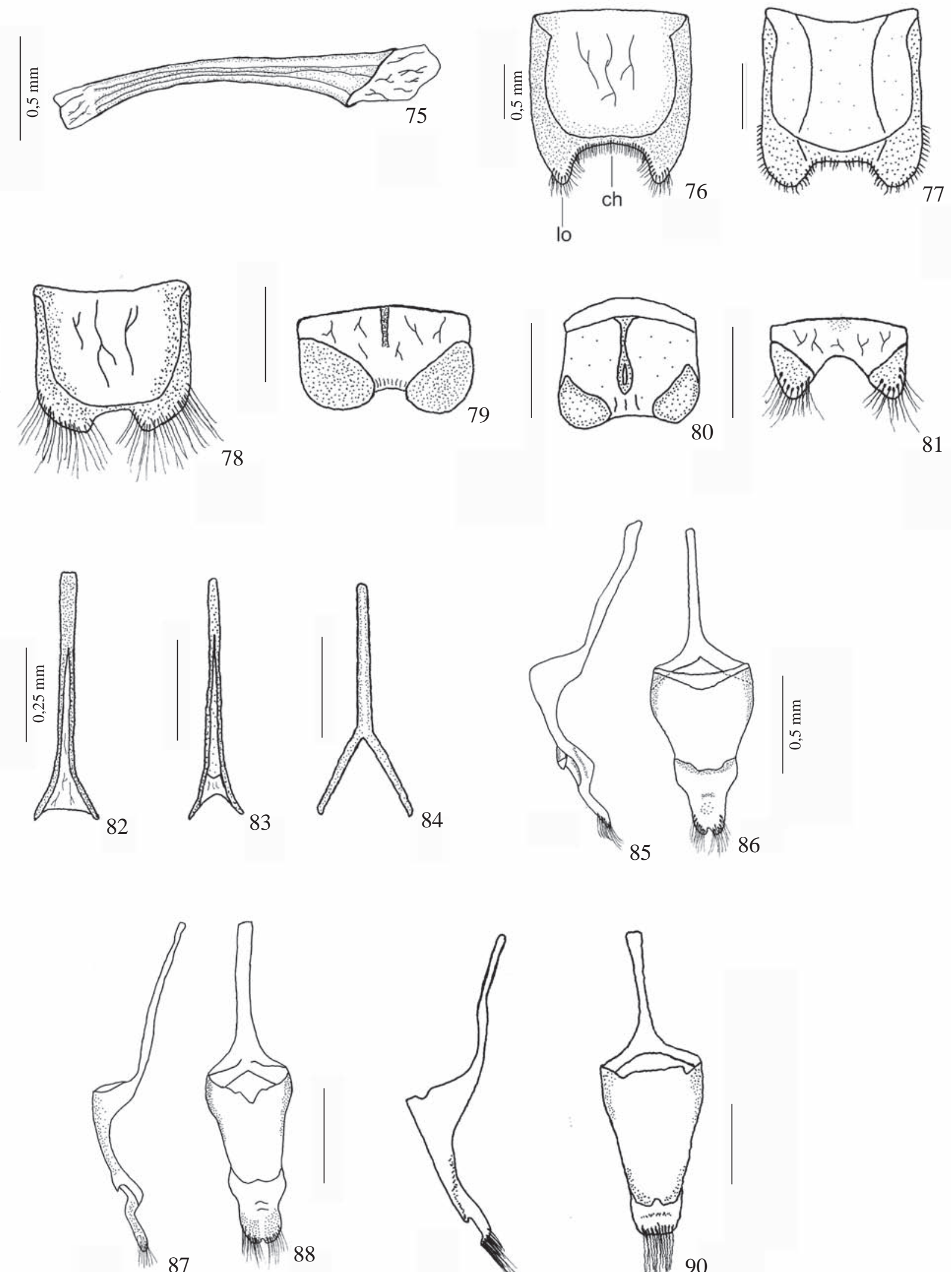

87
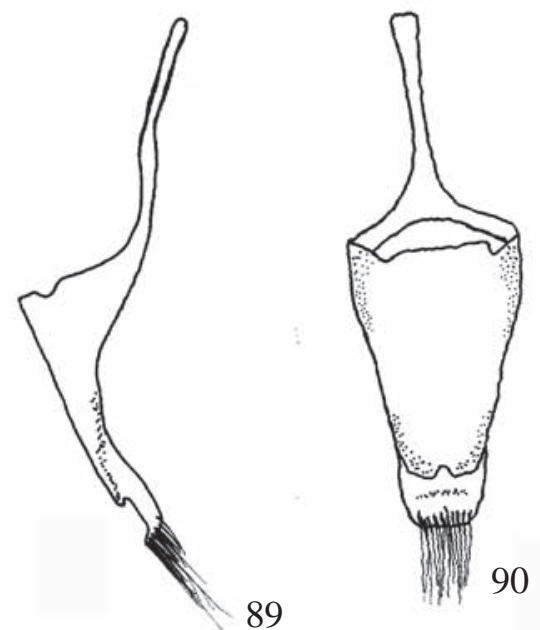

Figs. 75-90. 75, placas retais, Stenocerus fulvitarsis. 76-78, oitavo tergito, macho: 76, S. fulvitarsis; 77, S. longulus; 78, S. frontalis. 79-81, oitavo esternito, macho: 79, S. fulvitarsis; 80, S. longulus; 81, S. frontalis. 82-84, nono esternito, macho: 82, S. fulvitarsis; 83, S. longulus; 84, S. frontalis. 85-90, tégmen, vistas lateral e dorsal, respectivamente: 85, 86, S. fulvitarsis; 87, 88, S. longulus; 89, 90, S. frontalis; ch = chanfro; lo = lóbulo. Figs. 75-81, 85-90 e 82-84 respectivamente nas escalas de $0,5 \mathrm{~mm}$ e $0,25 \mathrm{~mm}$. 

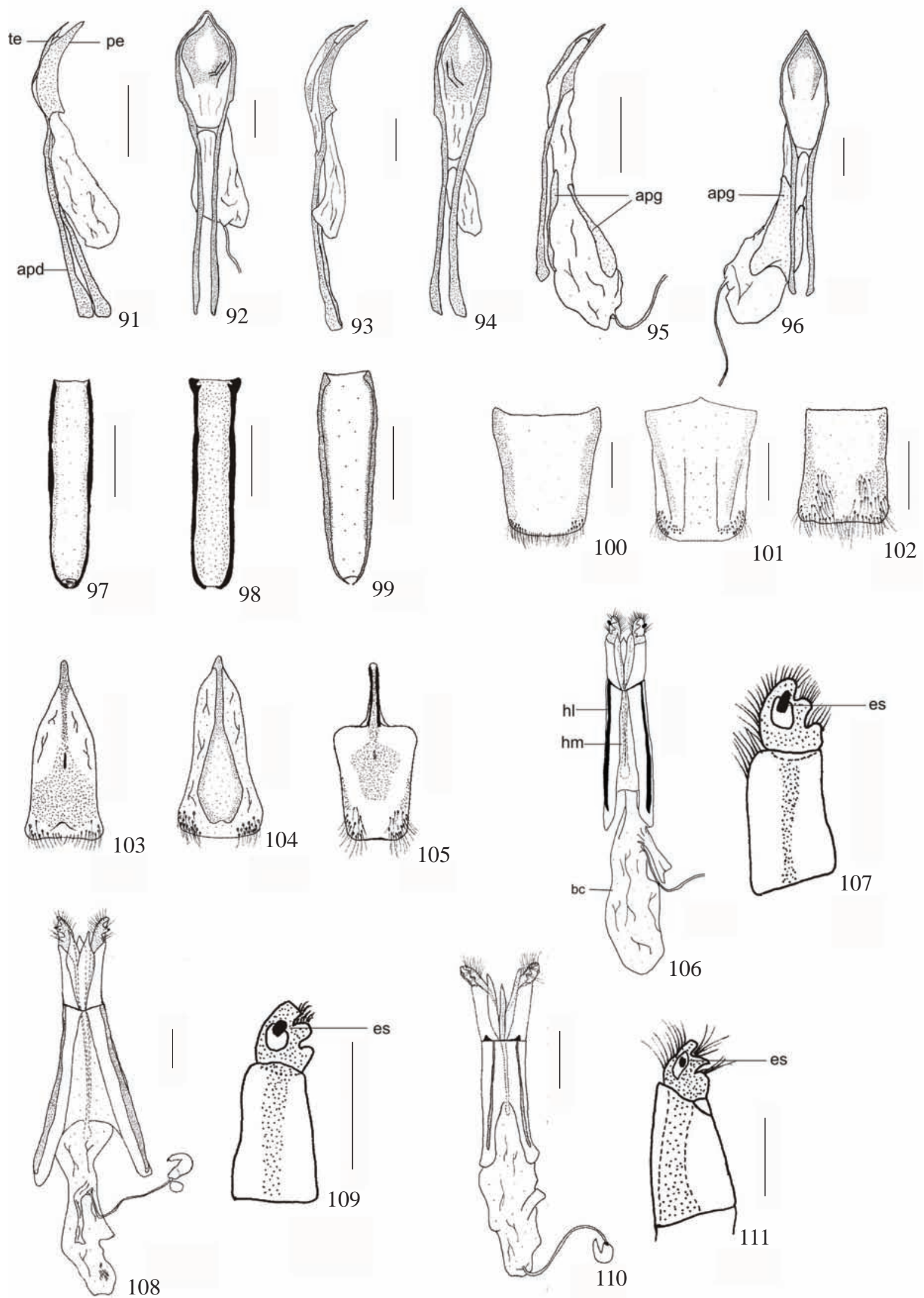

Figs. 91-111. 91-96, edeago, vistas lateral e dorsal, respectivamente: 91, 92, Stenocerus fulvitarsis; 93, 94, S. longulus; 95, 96, S. frontalis. 97-111, fêmea. 97-99, nono tergito: 97, S. fulvitarsis; 98, S. longulus; 99, S. frontalis. 100-102, oitavo tergito: 100, S. fulvitarsis; 101, S. longulus; 102, S. frontalis. 103-105, oitavo esternito: 103, S. fulvitarsis; 104, S. longulus; 105, S. frontalis. 106-111, ovipositor, vista ventral: 106, 107, S. fulvitarsis; 108, 109, S. longulus; 110, 111, $S$. frontalis; te = tectum; pe = pedon; apd = apódema; $\mathrm{apg}=$ área pigmentada; $\mathrm{hl}=$ haste lateral, $\mathrm{hm}=$ haste mediana; $\mathrm{bc}=$ bolsa copulatória; es $=$ estilo. Figs. 91-96,103-106,108,110; 97-102;107,109,111, respectivamente nas escalas de $1 \mathrm{~mm}, 0,5 \mathrm{~mm}$ e 0,25 mm. 
convergentes na porção proximal, hastes laterais alongadas e fortemente esclerotizadas. Oitavo tergito (Fig. 102) membranoso, cerca de 1,2x mais longo que largo, lados mais nitidamente pigmentados e ápice truncado. Oitavo esternito (Fig. 105) membranoso, com o comprimento desde o apódema cerca de duas vezes e meio mais longo que a largura da região apical; região central e lateral pigmentados, apódema curto, fortemente esclerotizado. Ovipositor (Figs. 110, 111) com o corpo distinto das hastes laterais, cerca de duas vezes mais curto que as hastes laterais; lobo dorsal ausente; lobos ventrais, medianos e laterais acuminados, estes últimos um pouco mais longo que o ventral; ápice esclerotizado, com três dentes, o dente proximal pouco arredondado, o mediano acuminado e o distal rombóide; estilos curtos e cilíndricos; hastes medianas delgadas, com comprimento entre a região das hastes transversas até o ápice menor que o comprimento das hastes laterais; bolsa copuladora desenvolvida, aproximadamente duas vezes mais longa que as hastes laterais; espermateca reniforme, mais nitidamente estreita na porção apical (glândula da espermateca não observada).

Dimensões em mm, macho/fêmea, respectivamente. CT $=8,9-9,4 / 9,2-11,9 ; \mathrm{CR}=1,4-1,6 / 1,4-1,7 ; \mathrm{LAR}=1,9-1,9 / 2,1-$ 2,3; LBR = 1,6-1,6/1,7-2,0; DEO = 0,4-0,5/0,3-0,4; MLO = 0,9-0,9/1,0-1,0; LP = 4,5-4,7/4,6-5,6; CP = 3,3-3,3/3,0-3,7; $\mathrm{CE}=5,6-6,1 / 6,2-8,2 ; \mathrm{LE}=4,4-4,7 / 4,8-6,7$.

Distribuição. Guiana, Brasil (Amazonas, Rio de Janeiro e Santa Catarina)(Valentine 1980). Acrescentamos Costa Rica e Brasil (Amapá, Pará, Espírito Santo, Minas Gerais e Paraná).

Material examinado. COSTA RICA. Puntarenas: Inbu San Luis, Monteverde, macho, XII.1993, Z. Fuentes col. (N447400-251450) \# 2862 (INBIO). Brasil. Amapá: Serra do Navio, fêmea, XI.2004, Magno \& Costa col. (MNRJ). Pará: Jambuaçu, macho, VII.1967 (sem coletor) E.P.D.Z. \& M.G. (MPEG); Benevides (Est. Neopolis, Sítio D. Doca), macho, V.1998, W. Overal col. (MPEG). Espírito Santo: Faz. Jerusalém, macho, 20.XI.1913 (sem coletor)(MNRJ). Minas Gerais: VIII.1980, fêmea, VIII.1980, B. Silva col. (MNRJ). Paraná: Rolândia, macho, I.1954, Dirings col. (MNRJ); Matelândia, fêmea, II.1962, macho, X.1961 (sem coletor)(MNRJ). Rio de Janeiro: Rio de Janeiro (Corcovado), macho, II.1962, Seabra \& Alvarenga col. (MNRJ); macho, fêmea, XI.1967, Alvarenga \& Seabra col. (Coleção Alvarenga)(MNRJ); macho, XI.1960, Alvarenga \& Seabra col. (Coleção M. Alvarenga)(MNRJ); fêmea, 30.X.1975, M. A. Monné \& C. A. Seabra col. (MNRJ); fêmea, 12.I.1971, Alvarenga \& Seabra col. (MNRJ); macho, 30.X.1975, M. A. Monné e C. A. Campos Seabra col. (MNRJ); macho, XII.1968, S. Fragoso col. (MNRJ).

Discussão. S. frontalis difere das demais espécies do gênero por apresentar no vértice e na fronte faixa longa e arqueada de pilosidade amarelada, olhos dorso-laterais, rostro curto, mais largo que longo (Fig. 9), élitros com faixas de pilosidade cinza brilhante intercaladas nas interestrias escutelar, 2, 4 e 6, e ausência de carena lateral (Fig. 42).

Considerações Finais. Valentine (1980) considerou os seguintes caracteres diagnósticos para o gênero: cerdas eretas nos antenômeros IV-XI; olhos não emarginados, laterais e ovais; rostro alargado no ápice e deprimido dorsalmente; escrobo látero-ventral; carena do protórax antebasal e processo mesosternal largo.
A análise comparada da morfologia das três espécies, incluindo a espécie-tipo $S$. fulvitarsis, possibilitou verificar que as cerdas eretas estão presentes a partir do antenômero III. Quanto aos olhos, são proeminentes, finamente facetados e com a margem anterior nitidamente arredondada. No rostro foi verificada uma fóvea no meio das depressões ventrais; esta fóvea também é observada nas espécies de Ptychoderes Schoenherr (Mermudes \& Napp 2006), mas neste gênero tem uma posição mais proximal ao sinus maxilar. A carena do protórax pode ser considerada sub-basal, se adotado o estudo de Holloway (1982).

O estudo da morfologia comparada de $S$. fulvitarsis, $S$. longulus e $S$. frontalis permitiu a descrição de caracteres em estruturas nunca antes estudadas como peças bucais, asas, endosternitos, terminálias do macho e da fêmea e placas retais. Além destas três espécies, foi incluído a comparação da morfologia externa de S. angulicollis Jekel, 1855 e S. nigrotessellatus Blanchard, 1846 os quais forneceram outros caracteres utilizados na análise comparativa e nas redescrições.

Os seguintes caracteres são compartilhados entre as três espécies estudadas: mandíbulas (Figs. 19-26) com a margem interna com dois dentes medianos fracamente desenvolvidos, mola basal desenvolvida, sub-retangular e fortemente côncava; maxila (Figs. 27, 28, 29 e 30) com gálea subcilíndrica e lacínia com cerdas longas, castanho-escura na região ventral e dorsal; superfície ventral do rostro com fóvea no meio de cada depressão lateral; clava das antenas (Figs. 16, 17 e 18) formada pelos antenômeros IX-XI, que são intumescidos, convexos no dorso e com faixa mediana subglabra, brilhante; carena sub-basal com unidades brácteas aproximadas; mesoscuto (Figs. 53, 54, 55) no disco com diminutos nódulos adensados e com projeções látero-anteriores; mesendosternito alongado (Fig. 52), curvo e dirigido para o mesepimero, com projeções laterais, expandido no ápice; asas desenvolvidas com a célula radial $(\mathrm{Rc})$ fechada quadrangular e reduzida, setor radial (Rs) desenvolvido; 3A, 4A e J com fraca esclerotização, transversas cu-a (Figs. 60, 61 e 62); intestino posterior com placas retais esclerotizadas, a ventral um pouco mais curta, as laterais discretamente mais longas que as ventrais, dorsal algo mais longa que as laterais; alça retal truncada e oblíqua (Fig. 75). No macho, oitavo tergito (Figs. 76, 77, 78) levemente mais longo que largo, esclerotizado lateralmente e no ápice, este chanfrado; edeago (Figs. 91-96) sem lobos no forâmen. Na fêmea, nono tergito (Figs. 97, 98 e 99) mais longo que a largura da base, oitavo tergito (Figs. 100, 101, 102) membranoso um pouco mais longo que largo, com lados pigmentados e ápice truncado.

Outros caracteres são compartilhados apenas por $S$. fulvitarsis (espécie-tipo) e S. longulus (entre parênteses, mencionamos o caráter distinto de S. frontalis): 1) cabeça como rostro mais longo que largo (rostro mais largo que longo) (Figs. 1-15); 2) olhos ocupam posição lateral, assim como as demais espécies do gênero (Figs. 7, 8, 10, 11, 13, 14) (posição dorso-lateral, Figs. 9, 12, 15); 3) mandíbulas com ápice projetado (Figs. 19, 20) (ápice pouco projetado, Fig. 21); 4) maxila: gálea e lacínia com o ápice truncado (Figs. 
27, 28, 29) (gálea e lacínia com o ápice arredondo, Fig. 30); 5) lábio com os palpígeros fusionados (Figs. 31, 32, 33, 34) (palpígeros individualizados, Figs. 35, 36); 6) carena lateral sem unidades brácteas (Figs. 40, 41) (carena lateral ausente (Fig. 42); 7) metendosternito com lâminas mais curtas que os braços (Figs. 56, 57) (lâminas mais longas que os braços, Figs. 58, 59); 8) comprimento da porção basal do pigídio subigual à metade apical (porção basal com um terço do comprimento, Figs. 72, 73, 74); 9) ápice do oitavo esternito com cerdas curtas e largura do chanfro apical maior que a largura dos lobos laterais (Figs. 76, 77) (cerdas apicais longas e largura do chanfro subigual à largura dos lobos apicais, Figs. 78); 10) edeago com duas hastes esclerotizadas (Figs. 91-94) e saco interno menor que o comprimento dos apódemas, sem áreas pigmentadas (sem hastes esclerotizadas, Figs. 95, 96; saco interno maior que o comprimento dos apódemas, com áreas dorsal e ventral pigmentadas); 11) ápice do ovipositor (Figs. 106-109) com três dentes subiguais e rombóides (com três dentes distintos entre si - o proximal pouco arredondado, o mediano acuminado e o distal rombóide, Fig. 111).

Desta forma, o estudo da morfologia permitiu o reconhecimento de novos caracteres e a reinterpretação de outros, além dos mencionados na literatura. S. frontalis apresenta várias características em comum com a espécie-tipo, porém distingue em outras, os quais o mantém no gênero, no entanto com restrições. Futuramente, os dados deste estudo fornecerão a base para uma investigação filogenética inédita.

Agradecimentos. Aos curadores das instituições pelo empréstimo de exemplares. Ao CNPq e à Faperj pela concessão de Bolsa de Iniciação Científica (Processo ${ }^{\circ}$ 114247/2007-2) e apoio financeiro (Processo APQ-1 $\mathrm{n}^{\circ}$ 170.502/2007 e APQ 4 n 171.020/2006). Aos dois consultores anônimos pelas sugestões.

\section{REFERÊNCIAS}

Alonso-Zarazaga, M. A. \& C. H. C. Lyal. 1999. A World Catalogue of Families and Genera of Curculionoidea (Insecta: Coleoptera) (Excepting Scolytidae and Platypodidae). Barcelona, Entomopraxis, $315 \mathrm{p}$.

Alonso-Zarazaga, M. A. \& C. H. C. Lyal. 2002. Addenda and corrigenda to a 'World Catalogue of Families and Genera of Curculionoidea (Insecta: Coleoptera)'. Zootaxa 63: 1-37.

Germar, E. F. 1824. Insectorium species novae aut minus cognitae, descriptionibus illustratae. Hendel, Halle. 624 p.

Gyllenhall, L. 1833. In: C. J. Schoenherr, Genera et species curculionidum, cum synonymia hujus familiae. Species novae aut hacterus minus cognitae, descriptionibus a Dom. Leonardo Gyllenhal, C. H. Boheman, et entomologis aliis illustratae. Lipsiae, Fleisher, Roret, Paris, 1:1-685.

Hespenheide, H. A. 1973. A novel mimicry complex: beetles and flies. Journal of Entomology (A) 48: 49-56.

Holloway, B. A. 1982. Anthribidae (Insecta: Coleoptera). Fauna of New Zealand 3. Wellington, DSIR, $269 \mathrm{p}$.

Jekel, H. 1855. Insecta Saundersiana; or characters of undescribed insects in the collection of William Wilson Saunders (Coleoptera, Curculionidae). Esq., F.R.S., F.L.S., \& c... Part I. Van Voorst, London, $1-153$.

Jordan, K. 1906. Insecta. Anthribidae. Biologia Centrali-Americana 4: 298-378.

Lacordaire, T. 1866. Histoire Naturelle des Insectes. Genera des Coléoptères ou exposé méthodique et critique de tous les genres proposés jusqu' ici dans cet ordre d'insectes 7. Paris, Roret, $620 \mathrm{p}$.

Mermudes, J. R. M. 2002. Systaltocerus platyrhinus Labram \& Imhoff, 1840: redescrições e considerações sobre a sinonímia com Homalorhamphus vestitus Haedo Rossi \& Viana, 1957 (Coleoptera, Anthribidae, Anthribinae). Revista Brasileira de Entomologia 46: 579-590.

Mermudes, J. R. M. 2003. Unanthribus, um novo gênero Neotropical de Ptychoderini Jekel, 1855 (Coleoptera, Anthribidae, Anthribinae). Revista Brasileira de Entomologia 47: 239-244.

Mermudes, J. R. M. 2005. Revisão Sistemática, Análise Cladística e Biogeografia dos gêneros Tribotropis e Hypselotropis (Coleoptera, Anthribidae, Anthribinae, Ptychoderini). Revista Brasileira de Entomologia 49: 465-511.

Mermudes, J. R. M. \& Napp, D. S. 2006. Revision and cladistic analysis of the genus Ptychoderes Schoenherr, 1823 (Coleoptera, Anthribidae, Anthribinae, Ptychoderini). Zootaxa 1182: 1-130.

Perty, J. A. M. 1832. Insecta Brasiliensia. In: Delectus animalium aeticulatorum, quae itinere per Brasiliam annis MDCCCXVIIMDCCCXX jussu et auspiciis Maximiliani Josephi I., Fasc. 2: 61-124.

Rheinheimer, J. 2004. Illustrater Katalog und Bibliographie de Anthribidae der Welt (Insecta, Coleoptera). Mitteilungen des Entomologischen Vereins Stuttgart 39: 3-242.

Schoenherr, C. J. 1826. Curculionidum dispositio methodica cum generum characteribus, descriptionibus atque observationibus variis seu prodromus ad Synonymiae Inectorum. Partem 4. Fleisher, Lipsiae, Roret, Paris, $\mathrm{x}+338 \mathrm{p}$.

Schoenherr, C. J. 1833. Genera et species curculionidum, cum synonymia hujus familiae. Species novae aut hacterus minus cognitae, descriptionibus a Dom. Leonardo Gyllenhal, C. H. Boheman, et entomologis aliis illustratae. Lipsiae, Fleisher, Roret, Paris, 1(12): $1-685$.

Valentine, B. D. 1980. The species of the Anthribid weevil genus Stenocerus Schoenherr. Coleopterists Bulletin 34: 287-294.

Zherikhin, V. V. \& V. G. Gratchev. 1995. A comparative study of the hind wing venation of the superfamily Curculionoidea, with phylogenetic implication, p. 633-777. In: Pakaluk, J. and S. A. Splipinski (eds.) Biology, phylogeny and classification of Coleoptera: paper celebrating the $\mathbf{8 0}^{\text {th }}$ birthday of Roy A. Crowson. Vol 2. Warszawa, Museum i Instytut Zoologii PAN, i-vi + 559-1092 p. 